\title{
SKRINING FITOKIMIA DAN ANALISIS KROMATOGRAFI LAPIS TIPIS EKSTRAK TANAMAN PATIKAN KEBO (Euphorbia hirta L.)
}

\section{(PHYTOCHEMICAL SCREENING AND THIN LAYER CHROMATOGRAPHIC STUDIES OF Euphorbia hirta L. EXTRACT)}

\author{
PUTU ERA SANDHI KUSUMA YUDA ${ }^{\bullet}$, ERNA CAHYANINGSIH ${ }^{1}$, \\ NI LUH PUTU YUNI WINARIYANTHI ${ }^{1}$ \\ ${ }^{1}$ Akademi Farmasi Saraswati Denpasar, Jalan Kamboja No 11A, Denpasar, Bali
}

\begin{abstract}
Abstrak: Tanaman obat mengandung berbagai macam kandungan fitokimia yang berperan dalam pengembangan obat. Herba Patikan Kebo (Euphorbia hirta L.) adalah salah satu tanaman obat yang tergolong dalam Famili Euphorbiaceae. Penggunaan E.hirta sebagai obat tradisional telah dilaporkan di beberapa daerah termasuk di Bali. Secara tradisional tanaman ini diketahui dapat digunakan untuk mengobati berbagai macam penyakit, seperti radang tenggorokan, disentri, diare, asma dan bronchitis sehingga berpotensi sebagai alternatif bahan baku obat tradisional. Untuk dapat dikembangkan sebagai bahan obat tradisional, perlu diketahui kandungan senyawa metabolit sekunder yang terdapat pada herba Patikan Kebo baik secara kualitatif maupun kuantitatif sebagai salah satu parameter standarisasi. Namun, saat ini data mengenai karakteristik metabolit sekunder herba Patikan Kebo yang tumbuh di Bali masih terbatas. Penelitian ini bertujuan untuk mengetahui senyawa metabolit sekunder yang terkandung pada herba Patikan Kebo melalui skrining fitokimia dan analisis Kromatografi Lapis Tipis (KLT). Ekstraksi dilakukan menggunakan pelarut etanol 75\% dengan cara maserasi, dan diperoleh rendemen ekstrak sebanyak 6,87\%. Pengujian kandungan metabolit sekunder pada ekstrak herba patikan kebo dilakukan secara skrining fitokimia. Selanjutnya uji KLT dilakukan untuk mempertegas keberadaan golongan senyawa yang positif pada skrining fitokimia, dan mengetahui profil kromatografi dari ekstrak tersebut. Setelah diuji secara skrining fitokimia dan analisis KLT, diperoleh hasil herba Patikan Kebo yang digunakan dalam penelitian ini mengandung beberapa senyawa metabolit sekunder diantaranya flavonoid, tanin, steroid dan antrakuinon. Sistem KLT yang digunakan dalam penelitian ini dapat memisahkan kandungan fitokimia tersebut dan memberikan hasil positif yang mempertegas hasil skrining fitokimia.
\end{abstract}

Kata kunci: Skrining, fitokimia, patikan kebo, KLT

\begin{abstract}
Medicinal plants contain a wide variety of chemicals that have important role in various applications including medicinal products. Euphorbia hirta is an important medicinal herb belongs to genus Euphorbia, family Euphorbiaceae. Traditional uses of E.hirta are recorded in some areas including in Bali. Euphorbia hirta is traditionally used to treat various diseases, such as strep throat, dysentery, diarrhea, asthma and bronchitis. Recent studies showed that E.hirta and its active components possessed wide pharmacological actions, such as anti-inflammatory, antifungal, antibacterial, anti-diarrheal, sedative, anxiolytic, analgesic, antipyretic and antioxidant. Most of its pharmacological actions are in line with the traditional efficacy. Thus, this plant is potentially developed as an alternative material for traditional medicine. The chemical constituents of E.hirta along with its pharmacological actions have been studied in various laboratories. To be developed as a traditional medicine, the photochemical content of the plant must be clearly established both qualitatively and quantitatively. However, current data on the characteristics of secondary metabolites of E.hirta growing in Bali is still limited. Current study was performed to determine the photochemical constituent contained in E.hirta extract by phytochemical screening and TLC analysis. The extraction has done using $75 \%$ ethanol solvent by maceration. Phytochemical screening was determined by some chemical tests and thin layer chromatographic study was carried out by using various solvent systems. The results of phytochemical screening indicated that E.hirta extract contains several secondary metabolite compounds including flavonoids, tannins, steroids and anthraquinones. Chromatographic profile that has been done can give positive result of those secondary metabolite compound indicating that the TLC systems used in this study could separate those phytochemical constituents from the extract.
\end{abstract}

Keywords: phytochemical, screening, E.hirta, TLC

• email korespondensi: sandhikusumayuda@gmail.com 


\section{PENDAHULUAN}

Masyarakat terkadang tidak menyadari bahwa tumbuhan yang tumbuh liar disekitarnya dapat dimanfaatkan sebagai obat untuk menyembuhkan penyakit dan pemeliharaan kesehatan. Senyawa metabolit sekunder yang terdapat dalam tumbuhan merupakan zat bioaktif yang berkaitan dengan kandungan kimia dalam tumbuhan, sehingga tumbuhan dapat digunakan sebagai bahan obat untuk berbagai macam penyakit (Titis dkk., 2013). Salah satu tumbuhan liar yang sering ditemukan di sekitar masyarakat yaitu herba Patikan Kebo (Euphorbia hirta L.). Berdasarkan penelitian yang dilakukan sebelumnya ekstrak heksana, kloroform dan metanol herba Patikan Kebo yang terdapat di daerah Surabaya mengandung senyawa metabolit sekunder diantaranya steroid, fenolik, flavonoid, tannin dan alkaloid (Nafisah dkk., 2014). Patikan Kebo yang diteliti di daerah Tamil Nadu, India positif mengandung senyawa fenolik, flavonoid, terpenoid dan tanin (Mathivanan dkk., 2014). Telah diketahui bahwa perbedaan habitat tanaman berpengaruh terhadap kandungan aktif tanaman tersebut. Namun, saat ini data mengenai karakteristik metabolit sekunder dari herba Patikan Kebo yang tumbuh di daerah Bali masih terbatas. Informasi mengenai karakteristik metabolit sekunder diperlukan dalam proses standarisasi sebuah tanaman sebagai bahan baku obat tradisional (Saifudin dkk., 2011). Berdasarkan latar belakang tersebut, peneliti tertarik untuk mengidentifikasi kandungan metabolit sekunder yang terkandung pada herba Patikan Kebo yang tumbuh di Bali. Penelitian ini menggunakan metode secara skrining fitokimia dan untuk mempertegas hasil positif pada skrining fitokimia, dilakukan analisis Kromatografi Lapis Tipis terhadap ekstrak etanol E.hirta. Penelitian ini bertujuan untuk mengetahui golongan senyawa metabolit sekunder yang terdapat pada herba Patikan Kebo yang tumbuh di Bali.

\section{BAHAN DAN METODE}

\section{Rancangan penelitian}

Penelitian ini merupakan penelitian dalam bentuk desktiptif laboratorik yang dilakukan secara kualitatif dengan metode skrining fitokimia dan KLT. Teknik sampling yang digunakan adalah purposive sampling. Sampel yang digunakan adalah seluruh bagian herba Patikan Kebo yang diambil di wilayah Denpasar pada bulan Januari 2017.

\section{Bahan}

Bahan yang digunakan dalam penelitian ini herba Patikan Kebo (Euphorbia hirta L.), etanol $75 \%$, aquadest, $\mathrm{HCl} 2 \mathrm{~N}$, pereaksi dragendroff, pereaksi mayer, $\mathrm{NaOH} 10 \%$, pereaksi LibermanBuchard, $\mathrm{Pb}$ asetat, larutan $\mathrm{AlCl}_{3}$, larutan $\mathrm{KOH}$ $10 \%, \mathrm{FeCl}_{3} 5 \%$, etil asetat, klorofom, methanol, nHeksan, butanol, asam asetat glasial, $\mathrm{H}_{2} \mathrm{SO}_{4} 10 \%$.

\section{Metode}

Adapun metode atau alur kerja dari penelitian ini adalah sebagai berikut:

\section{Ekstraksi}

a. Serbuk simplisia herba Patikan Kebo sebanyak 457,5 gram, dimaserasi dengan $1700 \mathrm{ml}$ pelarut etanol $75 \%$ dan diremaserasi sebanyak tiga kali dengan pelarut yang sama pada suhu ruangan selama 24 jam.

b. Filtrat disaring menggunakan corong Buchner untuk memisahkan filtrat dengan maserat.

c. Filtrat yang diporoleh dipekatkan menggunakan rotary evaporator pada suhu $40^{\circ} \mathrm{C}$ sampai diperoleh ekstrak kental.

\section{Skrining fitokimia}

Pembuatan larutan uji untuk skrining fitokimia dilakukan dengan melarutkan $500 \mathrm{mg}$ ekstrak dalam $50 \mathrm{~mL}$ pelarut yang sesuai.

a. Uji Alkaloid

Larutan uji sebanyak $2 \mathrm{ml}$ diuapkan diatas cawan porselin hingga diperoleh residu. Residu kemudian dilarutkan dengan $5 \mathrm{~mL} \mathrm{HCl} 2 \mathrm{~N}$. Setelah dingin, larutan disaring. Larutan yang didapat dibagi ke dalam 3 tabung reaksi. Tabung pertama berfungsi sebagai kontrol. Tabung ke 2 ditambahkan 3 tetes pereaksi dragendroff dan tabung ketiga ditambahkan 3 tetes pereaksi mayer (melalui dinding tabung). Terbentuknya endapan jingga pada tabung kedua dan endapan kuning pada tabung ketiga menunjukan adanya alkaloid (Farnsworth, 1966 dalam Putri dkk., 2015).

b. Uji Flavonoid

Sebanyak $1 \mathrm{ml}$ larutan uji masing-masing dimasukkan ke dalam 3 tabung reaksi. Tabung 1 sebagai kontrol, tabung 2 ditambah dengan $1 \mathrm{~mL}$ larutan $\mathrm{Pb}$ Asetat (timbal asetat) $10 \%$, positif flavonoid jika terdapat endapan kuning (Raphael, 2012). Tabung 3 ditambah dengan beberapa tetes $\mathrm{NaOH} 20 \%$ terbentuk warna kuning jika mengandung flavonoid (Ugochukwu dkk., 2013).

c. Tanin

Sebanyak $2 \mathrm{~mL}$ larutan uji dimasukkan ke dalam 2 tabung reaksi, tabung 1 sebagai kontrol dan tabung 2 ditambahkan beberapa tetes larutan $\mathrm{FeCl}_{3} 5 \%$ atau $\mathrm{FeCl}_{3} 10 \%$, tanda positif Tanin jika 
terbentuk warna hijau gelap/biru (Robinson, 1911 dalam Putri dkk., 2015).

d. Triterpenoid/Steroid

Larutan uji sebanyak $2 \mathrm{~mL}$ diuapkan dalam cawan penguap. Residu dilarutkan dengan $0,5 \mathrm{~mL}$ kloroform, dipindahkan ke tabung reaksi, ditambahkan $0,5 \mathrm{~mL}$ asam asetat anhidrat dan $2 \mathrm{~mL}$ asam sulfat pekat melalui dinding tabung. Terbentuknya cincin kecoklatan atau violet pada perbatasan larutan menunjukkan adanya triterpenoid, sedangkan bila muncul cincin biru kehijauan menunjukkan adanya steroid (Ciulei, 1984 dalam Putri dkk., 2015).

e. Antrakuinon

Sebanyak $50 \mathrm{mg}$ ekstrak ditambah $10 \mathrm{~mL}$ air kemudian dipanaskan selama 5 menit dan disaring. Sebanyak $3 \mathrm{~mL}$ larutan dimasukkan ke dalam 2 tabung reaksi, tabung 1 ditambahkan beberapa tetes larutan $\mathrm{NaOH} 1 \mathrm{~N}$ bila positif maka terbentuk larutan berwarna merah dan tabung 2 sebagai kontrol (Putri dkk., 2015).

f. Saponin

$4 \mathrm{~mL}$ larutan uji ditambahkan dengan $5 \mathrm{~mL}$ aquadest, kocok, lihat adanya busa yang stabil. Sedikit ekstrak ditambahkan $5 \mathrm{~mL}$ air, kocok dalam tabung reaksi, terbentuk busa stabil (busa setinggi $1 \mathrm{~cm}$ dan stabil selama 30 menit). $4 \mathrm{~mL}$ larutan uji dimasukkan ke dalam tabung reaksi sebagai kontrol (Depkes RI, 1995 dalam Putri dkk., 2015).

3. Kromatografi Lapis Tipis

Penyiapan fase diam Silica gel $\mathrm{G}_{60} \mathrm{~F}_{254} /$ plat KLT dengan panjang $8 \mathrm{~cm}$ dan lebar $2 \mathrm{~cm}$, kemudian dicuci dengan metanol, lalu diaktivasi dengan oven pada suhu $100^{\circ} \mathrm{C}$ selama 10 menit

Sebanyak $10 \mathrm{mg}$ ekstrak dilarutkan dalam $1 \mathrm{ml}$ etanol kemudian ditotolkan pada fase diam.

a. Identifikasi Senyawa Flavonoid

Fase gerak asam asetat glacial : butanol : air (1:4:5), dengan penampak noda uap ammonia. Reaksi positif ditunjukkan dengan terbentuknya noda berwarna kuning cokelat setelah diuapi ammonia pada pengamatan dengan sinar tampak dan berwarna biru pada UV $366 \mathrm{~nm}$ menegaskan adanya kandungan flavonoid (Marliana, 2005).

b. Identifikasi Senyawa Steroid

Fase gerak yang digunakan adalah Kloroform - metanol (9:1), dengan penampak noda pereaksi Liberman-Buchard disertai dengan pemanasan pada suhu $105^{\circ} \mathrm{C}$ selama 5 menit. Reaksi positif steroid ditunjukkan dengan adanya noda berwarna hijau biru (Kristanti dkk., 2008). c. Identifikasi Senyawa Tanin

Fase gerak metanol-air (6:4), dengan penampak noda Pereaksi $\mathrm{FeCl}_{3} 5 \%$. Reaksi positif ditunjukkan dengan terbentuknya noda berwarna hitam (Banu dan Nagarajan, 2014).

d. Identifikasi Senyawa Antrakuinon

Fase gerak yang digunakan adalah n-heksanetilasetat (3:7), dengan penampak noda larutan $\mathrm{KOH} 10 \%$ dalam metanol. Reaksi positif ditunjukkan dengan terbentuknya warna noda kuning,kuning cokelat, merah, ungu, hijau dan lembayung (Kristanti dkk., 2008).

\section{Pengolahan dan analisis data}

Data dari hasil penelitian ini dianalisis secara deskriptif dengan menjabarkan hasil yang diperoleh dalam bentuk tabel dan gambar serta melakukan analisis dengan membandingkan dengan literatur.

\section{HASIL}

1. Hasil skrining fitokimia

Skrining fitokimia dilakukan secara kualitatif dengan menggunakan pereaksi fitokimia. Berikut adalah hasil dari skrining fitokimia:

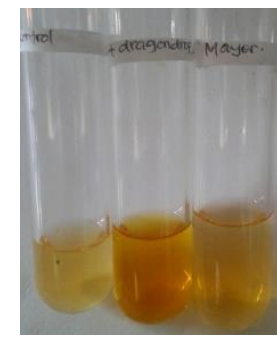

(a)

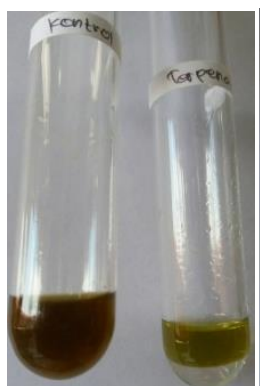

(d)

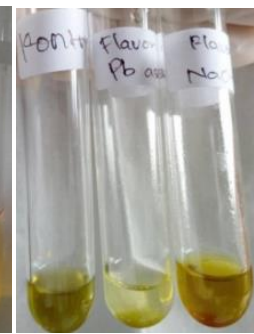

(b)

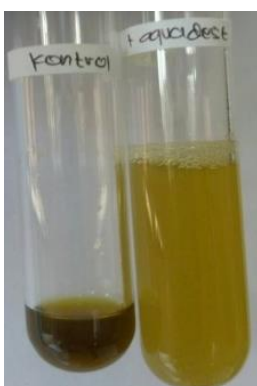

(e)

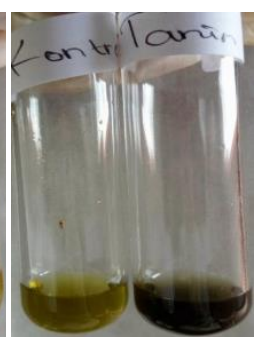

(c)
Gambar 1.Hasil Skrining Fitokimia. (a) Uji alkaloid dengan pereaksi dragendorf dan mayer, (b) uji flavonoid dengan pereaksi $\mathrm{Pb}$ asetat $10 \%$ dan $\mathrm{NaOH} 20 \%$, (c) uji tanin dengan pereaksi $\mathrm{FeCl}_{3} 5 \%$, (d) uji steroid dengan pereaksi Liberman Buchard, (e) uji saponin dengan aquadest, dan (f) uji antrakuinon dengan pereaksi $\mathrm{NaOH} 1 \mathrm{~N}$. 
Tabel 1 Hasil Skrining Fitokimia

\begin{tabular}{|c|c|c|c|c|}
\hline Senyawa & Pereaksi & $\begin{array}{l}\text { Tanda } \\
\text { Positif }\end{array}$ & HasilPengamatan & Kesimpulan \\
\hline Alkaloid & $\begin{array}{l}\text { - Dragendorf } \\
\text { - Mayer }\end{array}$ & $\begin{array}{l}\text { - Adanya endapan } \\
\text { oranye/merah coklat. } \\
\text { - Adanya endapan } \\
\text { putih/kuning. }\end{array}$ & $\begin{array}{l}\text { - Tidak adanya endapan } \\
\text { oranye/merah coklat. } \\
\text { - Tidak terbentuk } \\
\text { endapan putih/kuning }\end{array}$ & $\begin{array}{l}\text { Negatif } \\
\text { Negatif }\end{array}$ \\
\hline \multirow[t]{2}{*}{ Flavonoid } & $\begin{array}{l}\text { - Pbasetat } 10 \% \\
\text { - } \mathrm{NaOH} 20 \% \\
\end{array}$ & - Adanya endapan kuning & $\begin{array}{l}\text { - Adanya endapan } \\
\text { kuning }\end{array}$ & Positif \\
\hline & & $\begin{array}{l}\text { - Terbentuknya warna } \\
\text { kuning }\end{array}$ & $\begin{array}{l}\text { - Terbentuknya warna } \\
\text { kuning }\end{array}$ & Positif \\
\hline Tanin & $\mathrm{FeCl}_{3} 5 \%$ & $\begin{array}{l}\text { Terbentuk warna hijau gelap } \\
\text { /biru }\end{array}$ & $\begin{array}{l}\text { Terbentuk warna hujau } \\
\text { gelap/biru }\end{array}$ & Positif \\
\hline $\begin{array}{l}\text { Triterpenoid/ } \\
\text { Steroid }\end{array}$ & $\begin{array}{l}\text { Lieberman } \\
\text { Buchard }\end{array}$ & $\begin{array}{l}\text { Terbentuk cincin } \\
\text { kecokelatan/violet } \\
\text { (triterpenoid), cincin biru } \\
\text { kehijauan (steroid) }\end{array}$ & $\begin{array}{l}\text { Terbentuknya cincin biru } \\
\text { kehijauan } \\
\text { (steroid) }\end{array}$ & Positif \\
\hline Saponin & Aquadest & $\begin{array}{l}\text { Terbentuk busa stabil (busa } \\
\text { setinggi } 1 \mathrm{~cm} \text { selama } 10 \\
\text { menit) }\end{array}$ & $\begin{array}{l}\text { Tidak terbentuknya busa } \\
\text { stabil }\end{array}$ & Negatif \\
\hline Antrakuinon & $\mathrm{NaOH} 1 \mathrm{~N}$ & Terbentuknya warna merah & $\begin{array}{l}\text { Terbentuknya warna } \\
\text { merah }\end{array}$ & Positif \\
\hline
\end{tabular}

2. Hasil analisis Kromatografi Lapis Tipis

a. Flavonoid

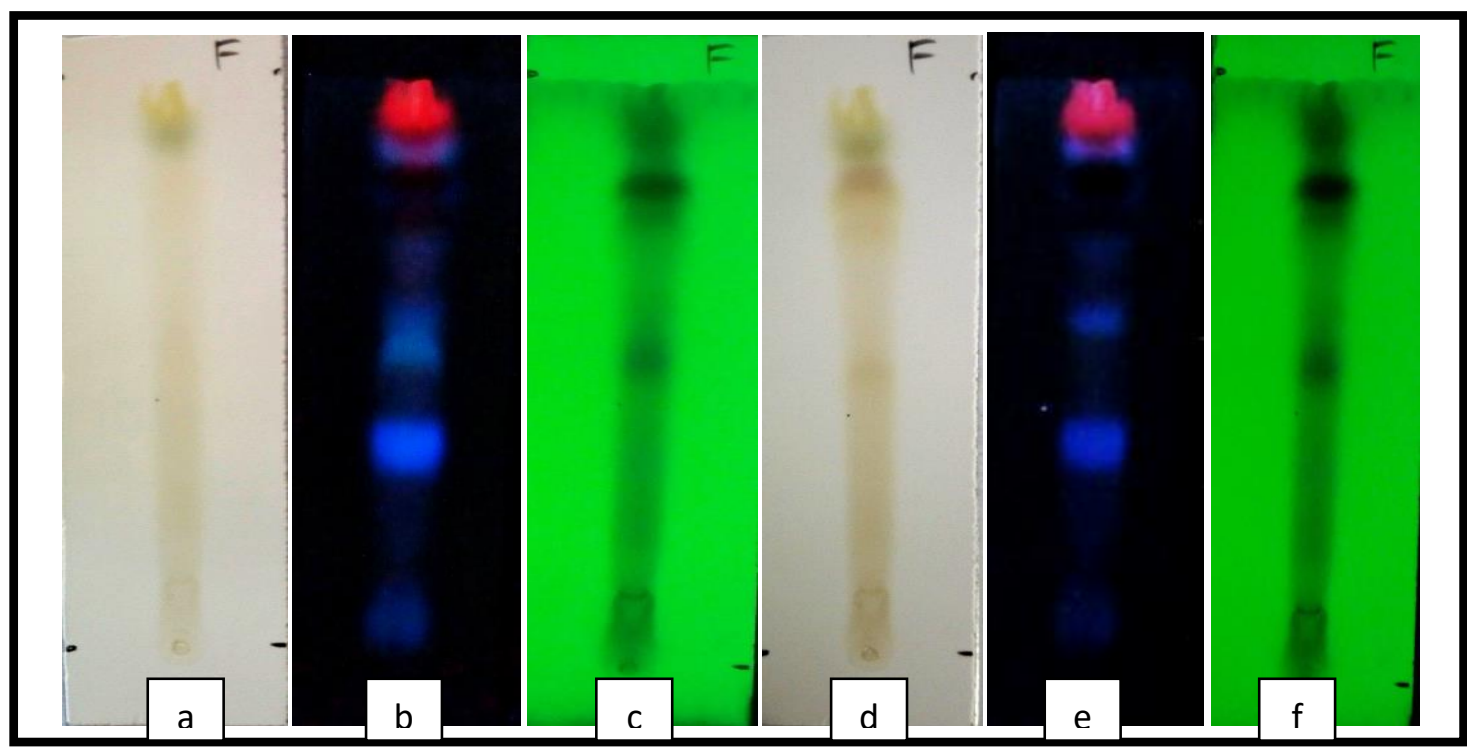

Gambar 2. Hasil KLT Identifikasi Senyawa Golongan Flavonoid, (a) Pengamatan pada sinar tampak, (b) Pengamatan pada sinar UV $366 \mathrm{~nm}$, (c) Pengamatan pada sinar UV $254 \mathrm{~nm}$, (d) Pengamatan pada sinar tampak setelah diuapi ammonia, (e) Pengamatan pada sinar UV 366 $\mathrm{nm}$ setelah diuapi ammonia, (f) Pengamatan pada sinar UV $254 \mathrm{~nm}$ setelah diuapkan ammonia. 
Tabel 2 Nilai Rf Hasil Elusi Ekstrak dengan Fase Gerak BAA (1:4:5)

\begin{tabular}{|c|c|c|c|c|c|c|}
\hline \multirow{2}{*}{ Rf } & \multicolumn{3}{|c|}{ Sesudah Elusi } & \multicolumn{3}{|c|}{ Sesudah Disemprot Ammonia } \\
\hline & Visual & UV $366 \mathrm{~nm}$ & UV 254 nm & Visual & UV $366 \mathrm{~nm}$ & UV $254 \mathrm{~nm}$ \\
\hline 0,93 & Kuning & Orange & Hitam & Hijau kekuningan & Orange & Hitam \\
\hline 0,87 & Hijau & Biru-merah & Hitam & Hijau & Biru-merah & Hitam \\
\hline 0,84 & Kuning & $\begin{array}{c}\text { Fluoresensi } \\
\text { biru muda }\end{array}$ & Hitam & $\begin{array}{c}\text { Kuning } \\
\text { kecokelatan }\end{array}$ & $\begin{array}{l}\text { Fluoresensi } \\
\text { murup biru } \\
\text { muda }\end{array}$ & Hitam \\
\hline 0,76 & Kuning & $\begin{array}{c}\text { Fluoresensi } \\
\text { biru muda }\end{array}$ & Hitam & $\begin{array}{c}\text { Kuning } \\
\text { kecokelatan }\end{array}$ & $\begin{array}{c}\text { Fluoresensi } \\
\text { murup biru } \\
\text { muda }\end{array}$ & Hitam \\
\hline 0,53 & Kuning & $\begin{array}{c}\text { Fluoresensi } \\
\text { biru muda }\end{array}$ & Hitam & $\begin{array}{c}\text { Kuning } \\
\text { kecokelatan }\end{array}$ & $\begin{array}{c}\text { Fluoresensi } \\
\text { murup biru } \\
\text { muda }\end{array}$ & Hitam \\
\hline 0,46 & Kuning & $\begin{array}{c}\text { Fluoresensi } \\
\text { biru muda }\end{array}$ & Hitam & $\begin{array}{c}\text { Kuning } \\
\text { kecokelatan }\end{array}$ & Tak nampak & Hitam \\
\hline
\end{tabular}

b. Tanin

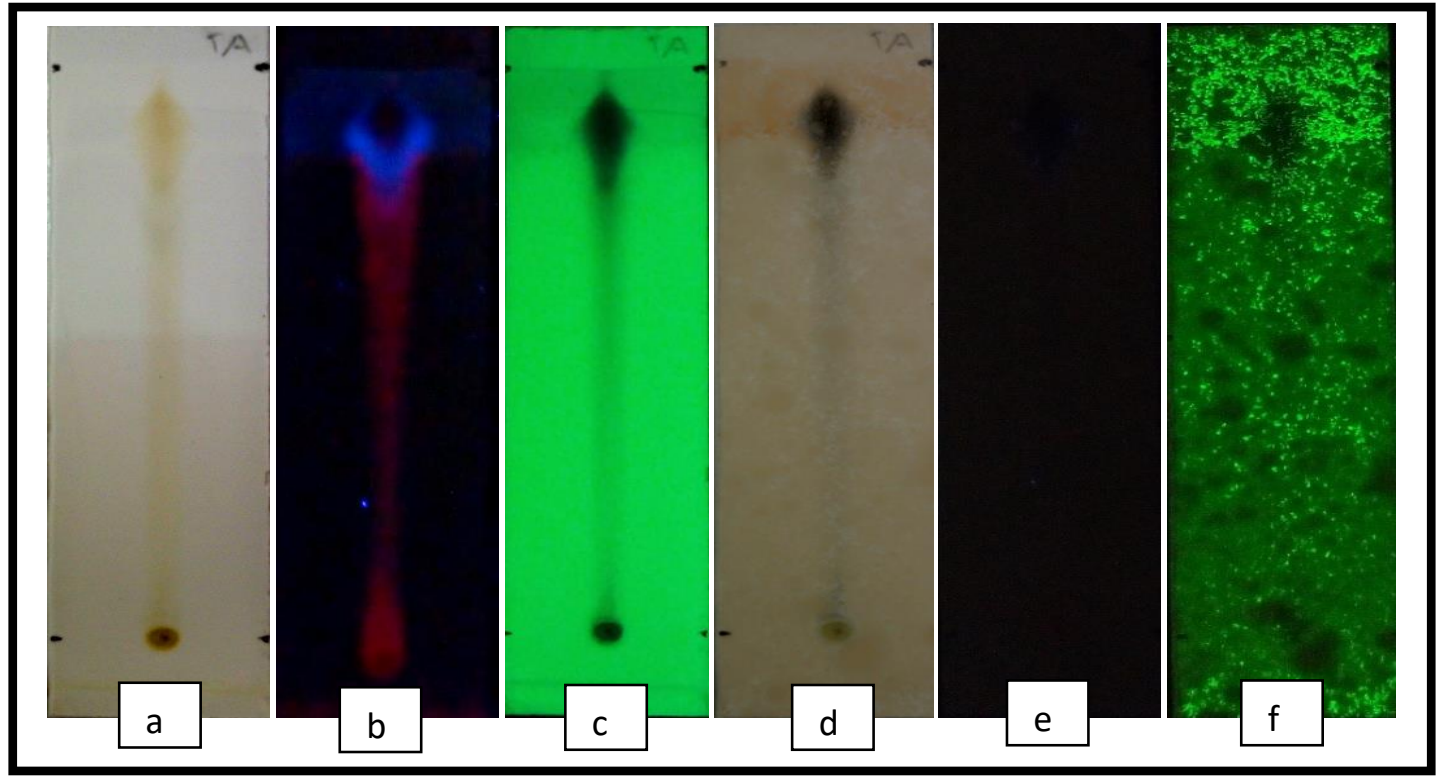

Gambar 3. Hasil KLT Identifikasi Senyawa Golongan Tanin. (a) Pengamatan pada sinar tampak, (b) Pengamatan pada sinar UV 366 nm, (c) Pengamatan pada sinar UV $254 \mathrm{~nm}$, (d) Pengamatan pada sinar tampak setelah disemprot $\mathrm{FeCl}_{3} 5 \%$, (e) Pengamatan pada sinar UV 366 nm setelah disemprot $\mathrm{FeCl}_{3} 5 \%$, (F) Pengamatan pada sinar UV $254 \mathrm{~nm}$ setelah disemprot $\mathrm{FeCl}_{3}$ $5 \%$

Tabel 3 Nilai Rf Hasil Elusi Ekstrak dengan Fase Gerak Metanol : Air (6:4)

\begin{tabular}{|c|c|c|c|c|c|c|}
\hline \multirow{2}{*}{ Rf } & \multicolumn{3}{|c|}{ Sesudah Elusi } & \multicolumn{3}{c|}{$\begin{array}{c}\text { Sesudah } \\
\text { Disemprot FeCl } 3 \text { 5\% }\end{array}$} \\
\cline { 2 - 7 } & Visual & $\begin{array}{c}\text { UV 254 } \\
\text { nm }\end{array}$ & UV 366 nm & Visual & UV 254 nm & $\begin{array}{c}\text { UV 366 } \\
\text { nm }\end{array}$ \\
\hline 0,87 & Kuning & Hitam & Hitam & Hitam & Hitam & Hitam \\
\hline 0,82 & Kuning & Biru & Hitam & Hitam & & Hitam \\
\hline 0,71 & Kuning & Merah & Hitam & Hitam & & \\
\hline 0,07 & Kuning & Merah & & Hitam & & \\
\hline
\end{tabular}


c. Steroid

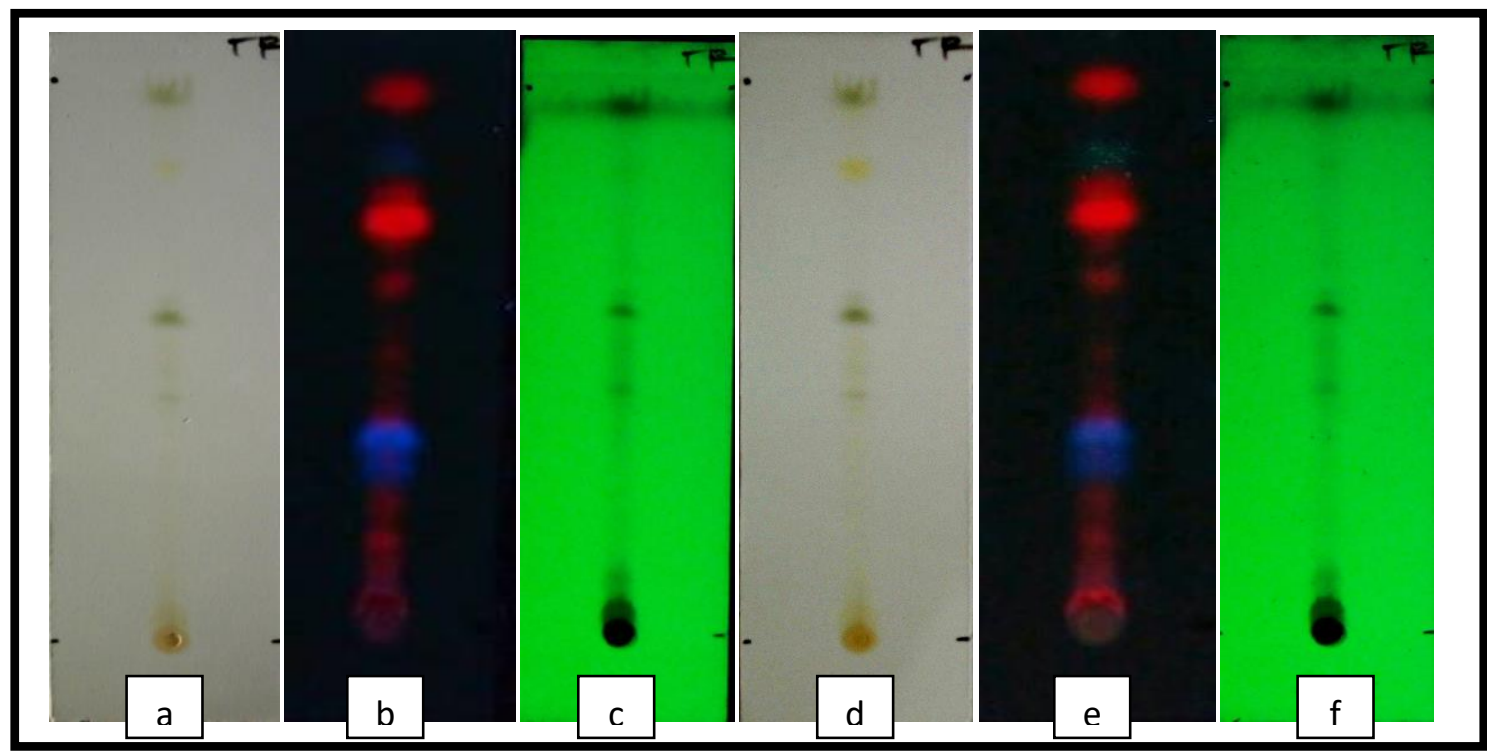

Gambar 4. Hasil KLT Identifikasi Senyawa Golongan Steroid. (a) Pengamatan pada sinar tampak, (b) Pengamatan pada sinar UV $366 \mathrm{~nm}$, (c) Pengamatan pada sinar UV $254 \mathrm{~nm}$, (d) Pengamatan pada sinar tampak setelah disemprot Lieberman Burchard, (e) Pengamatan pada sinar UV $366 \mathrm{~nm}$ setelah disemprot Lieberman Burchard, (f) Pengamatan pada sinar UV $254 \mathrm{~nm}$ setelah disemprot Lieberman Burchard.

Tabel 4 Nilai Rf Hasil Elusi Ekstrak dengan Fase Gerak Kloroform : Metanol (9:1)

\begin{tabular}{|c|c|c|c|c|c|c|}
\hline \multirow{2}{*}{ Rf } & \multicolumn{3}{|c|}{ Sesudah Elusi } & \multicolumn{3}{c|}{$\begin{array}{c}\text { Sesudah Disemprot } \\
\text { Lieberman Burchard }\end{array}$} \\
\cline { 2 - 7 } & Visual & UV 366 nm & $\begin{array}{c}\text { UV 254 } \\
\text { nm }\end{array}$ & Visual & UV 366 nm & $\begin{array}{c}\text { UV 254 } \\
\text { nm }\end{array}$ \\
\hline 0,96 & Hijau & Merah redup & Hitam & Hijau-biru & Merah & Hitam \\
\hline 0,85 & Kuning & & & Kuning & $\begin{array}{c}\text { Kuning } \\
\text { kehijauan }\end{array}$ & Hitam \\
\hline 0,80 & & Merah & Hitam & & Merah & Hitam \\
\hline 0,76 & & Orange & Hitam & & Orange & Hitam \\
\hline 0,62 & Hijau & Merah & Hitam & Hijau-biru & Merah & Hitam \\
\hline 0,48 & & Merah & Hitam & Kuning & Merah redup & Hitam \\
\hline 0,39 & & Merah & & Hijau-biru & Merah & \\
\hline 0,35 & & Biru terang & & & Biru redup & \\
\hline 0,29 & Hijau & Ungu & & Hijau & Ungu redup & \\
\hline 0,25 & & Merah & & & Merah & \\
\hline 0,17 & & Merah & & & Merah & \\
\hline 0,12 & & Merah & & Kuning & Merah & \\
\hline 0,08 & & Merah & & Orange & Merah terang & \\
\hline
\end{tabular}




\section{d. Antrakuinon}

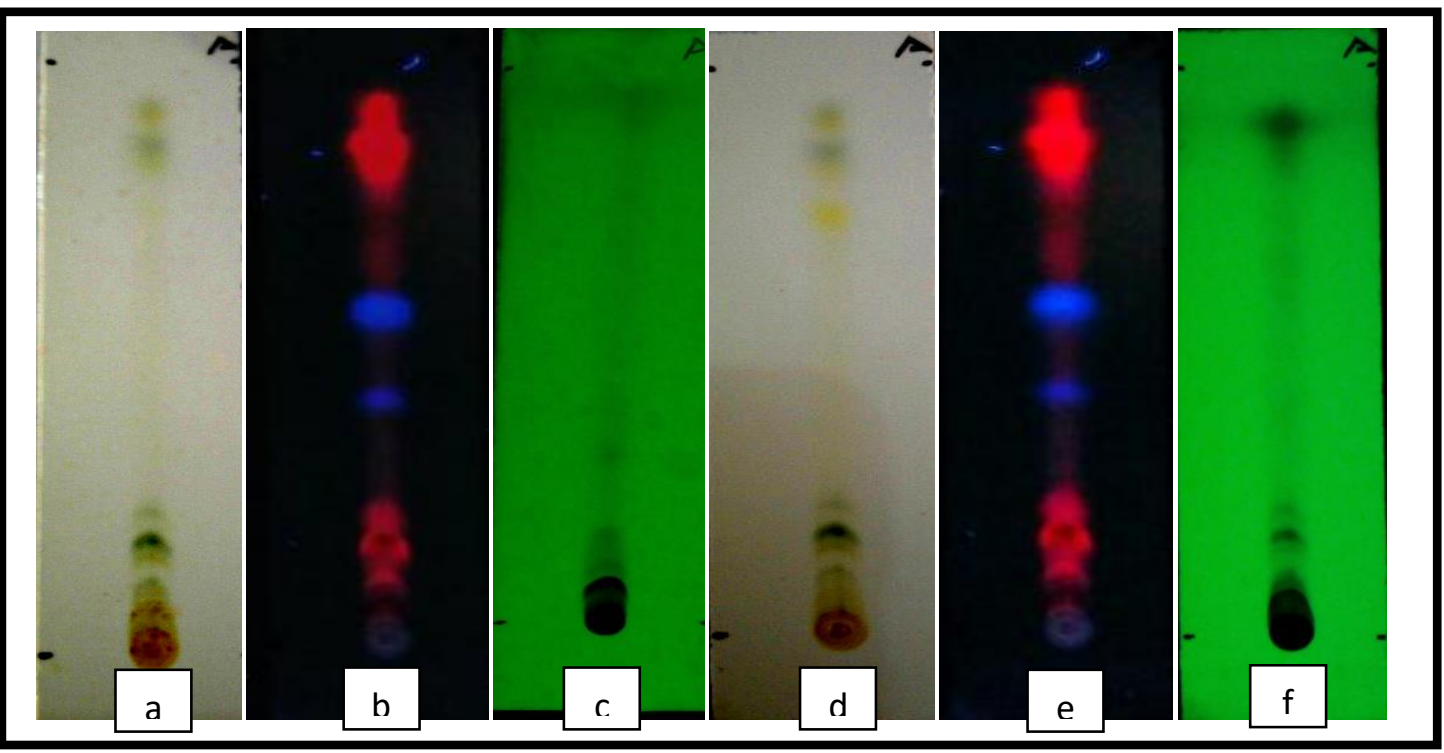

Gambar 5. Hasil KLT Identifikasi Senyawa Golongan Antrakuinon. (a) Pengamatan pada sinar tampak, (b) Pengamatan pada sinar UV 366 nm, (c) Pengamatan pada sinar UV 254 nm, (d) Pengamatan pada sinar tampak setelah disemprot larutan $\mathrm{KOH} 10 \%$ dalam metanol, (e) Pengamatan pada sinar UV $366 \mathrm{~nm}$ setelah disemprot larutan $\mathrm{KOH} \mathrm{10 \%} \mathrm{dalam} \mathrm{metanol,} \mathrm{(f)}$ Pengamatan pada sinar UV $254 \mathrm{~nm}$ setelah disemprot larutan $\mathrm{KOH} 10 \%$ dalam metanol.

Tabel 5 Nilai Rf Hasil Elusi Ekstrak dengan Fase Gerak n-Heksan : Etil Asetat (3:7)

\begin{tabular}{|c|c|c|c|c|c|c|}
\hline \multirow[t]{2}{*}{$\mathbf{R f}$} & \multicolumn{3}{|c|}{ Sesudah Elusi } & \multicolumn{3}{|c|}{$\begin{array}{c}\text { Sesudah } \\
\text { Disemprot KOH } 10 \% \text { dalam metanol }\end{array}$} \\
\hline & Visual & UV 366 nm & $\begin{array}{c}\text { UV } 254 \\
\text { nm }\end{array}$ & Visual & UV 366 nm & $\begin{array}{c}\text { UV } 254 \\
\text { nm }\end{array}$ \\
\hline 0,91 & Hijau & Orange redup & Hitam & Hijau kekuningan & Orange & Hitam \\
\hline 0,84 & Hijau & Orange & & Hijau & Orange & Hitam \\
\hline 0,79 & & & & Kuning & Orange & \\
\hline 0,73 & & Merah & & Kuning & Merah & Hitam \\
\hline 0,67 & & Merah & & & Merah & \\
\hline 0,52 & Kuning & $\begin{array}{l}\text { Fluoresensi } \\
\text { biru murup }\end{array}$ & & Kuning & $\begin{array}{l}\text { Fluoresensi } \\
\text { biru }\end{array}$ & \\
\hline 0,39 & & Ungu murup & & Kuning & Ungu & \\
\hline 0,23 & Hijau & Orange & Hitam & Hijau & Orange & Hitam \\
\hline 0,19 & Hijau & $\begin{array}{c}\text { Orange dengan } \\
\text { titik hitam } \\
\text { ditengahnya }\end{array}$ & Hitam & Hijau muda & $\begin{array}{c}\text { Orange dengan } \\
\text { titik hitam } \\
\text { ditengahnya }\end{array}$ & \\
\hline 0,17 & $\begin{array}{c}\text { Kuning } \\
\text { kehijauan }\end{array}$ & Orange redup & Hitam & Hijau & Orange & Hitam \\
\hline 0,15 & Hijau & Orange redup & & Hijau & Orange & \\
\hline 0,10 & $\begin{array}{c}\text { Hijau } \\
\text { kekuningan }\end{array}$ & & & Hijau kekuningan & & \\
\hline 0,06 & Kuning & & & Kuning & & \\
\hline 0,03 & $\begin{array}{c}\text { Cokelat } \\
\text { kekuningan }\end{array}$ & Merah redup & & $\begin{array}{l}\text { Cokelat dengan } \\
\text { warna kuning } \\
\text { ditengahnya }\end{array}$ & Merah & \\
\hline
\end{tabular}




\section{PEMBAHASAN}

Salah satu tumbuhan yang sering tumbuh liar dan berada di sekitar masyarakat serta dapat digunakan sebagai bahan obat tradisional yaitu herba Patikan Kebo (Euphorbia hirta L.). Agar dapat digunakan sebagai bahan baku obat tradisional maka perlu dilakukan standarisasi. Salah satu parameter standarisasi bahan obat tradisional yaitu informasi mengenai kandungan metabolit sekunder dan profil KLT dari ekstrak tanaman tersebut (Saifudin dkk., 2011). Penelitian ini dilakukan untuk mengetahui kandungan metabolit sekunder yang terkandung dalam ekstrak etanol Patikan Kebo melalui skrining fitokimia dan KLT. Tahap awal penelitian adalah pengumpulan herba Patikan Kebo, kemudian dicuci bersih lalu dikeringkan dengan cara diangin-anginkan pada suhu ruang dan tidak dibawah sinar matahari langsung. Pengeringan dilakukan hingga herba Patikan Kebo seluruhnya benar-benar kering, yang dimana mudah dipatahkan dan dihaluskan. Pengeringan simplisia menghasilkan bobot kering 44,5\% dari berat tanaman segar.

Tahap selanjutnya dilakukan ekstraksi, menggunakan metode maserasi, yang mempunyai beberapa kelebihan antara lain alat yang digunakan sederhana, hanya dibutuhkan bejana perendaman tetapi menghasilkan produk yang baik, selain itu dengan teknik ini zat-zat yang tidak tahan panas tidak akan rusak (Ningsih, 2016). Pada tahap ekstraksi sebanyak 457,5 gram serbuk simplisia herba Patikan Kebo diekstraksi dengan metode maserasi menggunakan pelarut etanol 75\% hingga diperoleh eksrak kental sebanyak 31,44 gram (rendemen ekstrak 6,87\%).

Pada ekstrak dilakukan skrining fitokimia dan didapatkan hasil negatif pada senyawa golongan alkaloid, triterpenoid dan saponin, seperti yang terlihat pada gambar 1 dan tabel 1 . Hasil positif diperolah pada senyawa golongan flavonoid, tanin, steroid dan antrakuinon. Setelah dilakukan skrining fitokimia, kemudian dilakukan uji KLT untuk mempertegas hasil positif yang diperoleh dari skrining fitokimia. Uji KLT flavonoid dilakukan dengan fase gerak BAA (1:4:5) dan penampak noda uap ammonia. Eluen ini menghasilkan enam spot noda dengan nilai Rf 0,$93 ; 0,87 ; 0,84 ; 0,76 ; 0,53$ dan 0,46 (Tabel 2). Dari hasil KLT terlihat adanya noda berwarna kuning cokelat setelah diuapkan dengan ammonia dan berflouresensi biru pada UV $366 \mathrm{~nm}$ pada Rf 0,76 yang diduga adalah senyawa golongan flavonoid. Menurut Markham (1998), terdapat penafsiran warna bercak dari segi struktur flavonoid, yang dimana pada sinar UV $366 \mathrm{~nm}$ sebelum diuapkan dengan ammonia terdapat noda fluoresensi biru muda dan setelah diuapkan dengan ammonia yang terjadi perubahan warna sedikit atau tanpa perubahan atau menjadi fluoresensi murup biru muda maka jenis flavonoid yang mungkin terkait yaitu Isoflavon yang tak mengandung 5-OH bebas, seperti yang terlihat pada gambar 2. Penelitian lain yang telah dilakukan juga menunjukkan hasil positif flavonoid yang terkandung dalam Patikan Kebo (Nafisah dkk., 2014; Miharja dkk., 2001; Harlis, 2010; Karim dkk., 2015).

Identifikasi senyawa tanin dengan uji KLT menggunakan fase gerak metanol : air (6:4) dan diperoleh empat spot hasil pemisahan dengan nilai Rf 0,87; 0,82;0,71 dan 0,07. Diduga pada Rf 0,87 adalah senyawa tanin karena noda berwarna hitam setelah disemprot dengan $\mathrm{FeCl}_{3} 5 \%$, seperti yang terlihat pada gambar 3. Hasil ini selaras dengan hasil penelitian lainnya yang menunjukkan bahwa herba Patikan Kebo mengandung senyawa tannin (Nafisah dkk., 2014; Miharja dkk., 2001; Harlis, 2010; Karim dkk., 2015).

Selanjutnya dilakukan uji KLT untuk mempertegas hasil skrining fitokimia terhadap senyawa steroid dengan fase gerak kloroform:metanol (9:1). Dari hasil elusi diperoleh 13 spot hasil pemisahan dengan nilai Rf yaitu 0,96 ; 0,$85 ; 0,80 ; 0,76 ; 0,62 ; 0,48 ; 0,39 ; 0,35 ; 0,29 ; 0,25$; 0,$17 ; 0,12$ dan 0,08 . Diduga pada Rf 0,$96 ; 0,62$ dan 0,39 merupakan senyawa steroid karena adanya noda berwarna hijau-biru setelah disemprot dengan pereaksi Liberman-Buchard, seperti yang terlihat pada gambar 4. Penelitian lain yang telah dilakukan juga menunjukkan hasil positif steroid yang terkandung dalam Patikan Kebo (Nafisah dkk., 2014; Miharja dkk., 2001).

Hasil positif yang juga terdapat pada skrining fitokimia herba Patikan Kebo yaitu senyawa antrakuinon, untuk mempertegas hasil, maka dilakukan uji KLT dengan fase gerak n-heksan:etil asetat (3:7) dan diperoleh sebanyaj 14 spot noda dengan nilai $\operatorname{Rf} 0,91 ; 0,84 ; 0,79 ; 0,73 ; 0,67 ; 0,52$; 0,$39 ; 0,23 ; 0,19 ; 0,17 ; 0,15 ; 0,10 ; 0,06 ; 0,03$. Fase gerak ini menghasilkan spot pemisahan paling banyak diantara fase gerak lainnya yang digunakan dalam penelitian ini. Diduga pada Rf 0,79 dan 0,73 merupakan senyawa antrakuinon karena terbentuk noda warna kuning setelah disemprot dengan larutan $\mathrm{KOH} 10 \%$ dalam metanol, seperti yang terlihat pada gambar 5. Hasil ini juga menunjukkan bahwa eluen $n$-heksana:etil asetat (3:7) merupakan eluen yang baik untuk pemisahan komponen dalam ekstrak herba Patikan Kebo.

Dari penelitian yang dilakukan secara skrining fitokimia dan uji KLT pada ekstrak etanol herba Patikan Kebo yang tumbuh di Bali, diperoleh hasil 
positif mengandung senyawa golongan flavonoid, tanin, steroid dan antrakuinon. Dari penelitian yang dilakukan oleh Nafisah dkk. (2014), diketahui bahwa ekstrak kloroform dan heksana Patikan Kebo yang diteliti di daerah Surabaya mengandung senyawa steroid, fenolik, flavonoid, tanin dan alkaloid. Sementara ekstrak kloroform, etil asetat dan metanol Patikan Kebo di Tamil Nadu, India positif mengandung senyawa fenolik, flavonoid, terpenoid dan tanin (Mathivanan dkk., 2014). Dari penelitian ini dihasilkan tambahan informasi bahwa herba Patikan Kebo yang tumbuh di daerah Bali mengandung senyawa antrakuinon. Namun alkaloid tidak ditemukan pada ekstrak yang diteliti. Perbedaan ini diduga disebabkan oleh pelarut yang digunakan saat ekstraksi dan pengaruh lingkungan tempat tumbuh tanaman yaitu iklim, kualitas tanah, dan mutu air yang dapat mempengaruhi kualitas dan kuantitas metabolit sekunder (Saifudin dkk., 2011). Dari hasil profil kromatografi yang telah didapatkan, diperoleh hasil senyawa metabolit sekunder yang positif terkandung pada ekstrak herba Patikan Kebo yaitu senyawa golongan flavonoid, steroid, tanin dan antrakuinon. Pemisahan yang paling baik yaitu menggunakan eluen n-Heksan : Etil asetat (3:7), karena dapat memberikan hasil pemisahan terbaik dengan 14 spot noda yang terlihat pada UV $366 \mathrm{~nm}$. Dari salah satu aspek parameter spesifik yang salah satunya telah dilakukan yaitu mengetahui senyawa metabolit sekunder secara kualitatif, maka herba Patikan Kebo yang tumbuh di Bali berpotensi dijadikan bahan obat tradisional, namun perlu dilakukan penelitian dari aspek parameter yang lainnya.

\section{SIMPULAN}

Dari hasil penelitian yang dilakukan secara skrining fitokimia dan Kromatografi Lapis Tipis dapat disimpulkan bahwa herba Patikan Kebo (Euphorbia hirta L.) yang tumbuh di daerah Bali mengandung senyawa flavonoid, tanin, steroid dan antrakuinon.

\section{DAFTAR PUSTAKA}

Banu, R. H., Nagarajan, N. 2014, TLC and HPTLC fingerprinting of leaf extracts of Wedelia chinensis (Osbeck) Merrill, Journal of Pharmacognosy and Phytochemistry, 2(6), 29-33

Harlis. 2010. Uji Aktivitas Anti Bakteri Ekstrak Patikan Kerbau (Euphorbia hirta L.)
Terhadap Pertumbuhan Bakteri Penyebab Diare (Eschercia coli), FKIP Universitas Jambi, Jambi

Karim, Karina., Minarni, R.Jura., Sri, Mulyani. S., 2015, Uji Aktivitas Antioksidan Ekstrak Daun Patikan Kebo (Euphorbia hirta L.),FKIP, Universitas Tadulako, Palu

Kristanti, A. N., Aminah, N. S., Tanjung , M., Kurniadi, B. 2008, Buku Ajar Fitokimia, Airlangga University Press, Surabaya

Markham, K. R. 1988, Cara Mengidentifikasi Flavonoid, Terjemahan oleh Kosasih Padmawinata, ITB, Bandung

Marliana, S. D., Suryanti, V., Suyono. 2005, Skrining Fitiokimia dan Analisis Kromatografi Lapis Tipis Komponen Kimia Buah Labu Siam (Sechium edule jacq. Swartz.) dalam Ekstrak Etanol, FMIPA, Universitas Sebelas Maret (UNS), Surakarta

Mathivanan K, Rengasamy D, Rajesh V, Palani R, P.Jayaraman, 2014, Phytochemical Potential of Euphorbia hirta Linn. and Strychnos nux- vomica Linn. With Reference to Antidiabetic and Antioxidant Properties, Journal of Pharmacognosy and Phytochemical, 6(4), 1024-1031

Miharja, Laurentia., Cornelis, Adimunca., Luice, Widowati., Raflizar., Pujiastuti., Winarno., Bambang, Wahjoedi. 2001. Manfaat Ekstrak Etanol Patikan Kebo (Euphorbia hirta L.) Sebagai Laktagogum Tikus Putih yang Menyusui, Puslitbang Farmasi

Nafisah,M., Tukiran., Suyanto., Nurul, Hidayati. 2014, Uji Skrining Fitokimia Pada Ekstrak Heksan, Kloroform, Dan Metanol Dari Tanaman Patikan Kebo (Euphorbia hirta), Jurusan FMIPA, Prosiding Seminar Nasional Kimia Surabaya, 20 September 2014, Universitas Negeri Surabaya, 279286

Ningsih, D.R., Zusfahair., Dwi, Kartika. 2016, Identifikasi Senyawa Metabolit Sekunder serta Uji Aktivitas Ekstrak Daun Sirsak Sebagai Antibakteri, FMIPA, Universitas Jenderal Soedirman, Purwokerto 
Putri, W.S., Warditiani, N.K., Larasanty, L.P.F. 2015, Skrining Fitokimia Ekstrak Etil Asetat Kulit Buah Manggis (Garcinia mangostana L.I), Fakultas Matematika dan IPA, Universitas Udayana, Jimbaran

Saifudin, Aziz., Rahayu, Viesa., Teruna, H.D. 2011. Standarisasi Bahan Obat Alam, Edisi pertama, Graha Ilmu, Yogyakarta, Indonesia
Titis, Muhamad., Enny Fachriyah, and Dewi Kusrini. 2013. Isolasi, Identifikasi dan Uji Aktifitas Senyawa alkaloid Daun Binahong (Anredera Cardifolia (Tenore) Steenis), Universitas Diponegoro, Semarang

Ugochukwu, S. C., Arukwe, U.I., Onuoha, I. 2013, Preliminary phytochemical screening of different solvent extracts of stem bark and roots of Dennetia tripetala G. Baker, Asian Journal of Plant Science and Research, 3(3), 10-13 